\title{
Effect of Soaking Temperature on Water Absorption Characteristics of Selected Ghanaian Cowpea Varieties
}

\author{
Nancy Nelly Idun-Acquah ${ }^{1}$, Ahmad Addo² ${ }^{2}$ Ato Bart-Plange ${ }^{2}$ \\ ${ }^{1}$ CSIR-Food Research Institute, Council for Scientific and Industrial Research, Accra, Ghana \\ ${ }^{2}$ Department of Agricultural and Biosystems Engineering, Kwame Nkrumah University of Science and Technology, Kumasi, \\ Ghana \\ Email: essaaba@yahoo.com
}

How to cite this paper: Idun-Acquah, N.N., Addo, A. and Bart-Plange, A. (2019) Effect of Soaking Temperature on Water Absorption Characteristics of Selected Ghanaian Cowpea Varieties. Open Journal of Applied Sciences, 9, 736-748.

https://doi.org/10.4236/ojapps.2019.99060

Received: July 29, 2019

Accepted: September 23, 2019

Published: September 26, 2019

Copyright $\odot 2019$ by author(s) and Scientific Research Publishing Inc. This work is licensed under the Creative Commons Attribution International License (CC BY 4.0).

http://creativecommons.org/licenses/by/4.0/

\begin{abstract}
The water absorption kinetics of three cowpea varieties (Asontem, Hewale and Asomdwee) was studied following the phenomenological models derived from Fick's law of diffusion. Soaking of seeds from each cowpea variety was carried out for $10 \mathrm{~h}$ at four temperatures $\left(30^{\circ} \mathrm{C}, 40^{\circ} \mathrm{C}, 50^{\circ} \mathrm{C}\right.$ and $\left.60^{\circ} \mathrm{C}\right)$. The saturation moisture content was higher for Asontem $(106.9 \mathrm{~g}$ water $/ 1000 \mathrm{~g}$ dry weight) and Hewale varieties (108.7 $\mathrm{g}$ water/1000 $\mathrm{g}$ dry weight) and lower for Asomdwee hybrid (100.7 g water/1000 g dry weight), respectively. The proposed Fick's law of diffusion satisfactorily described the kinetics of water absorption regardless of the variety and temperature. The estimated values for water diffusion coefficient for Asontem, Hewale and Asomdwee varied from $5.12 \times 10^{-10} \mathrm{~m}^{2} / \mathrm{s}$ to $6.64 \times 10^{-10} \mathrm{~m}^{2} / \mathrm{s}, 3.96 \times 10^{-10} \mathrm{~m}^{2} / \mathrm{s}$ to $5.12 \times 10^{-10} \mathrm{~m}^{2} / \mathrm{s}$, $4.93 \times 10^{-10} \mathrm{~m}^{2} / \mathrm{s}$ to $6.08 \times 10^{-10} \mathrm{~m}^{2} / \mathrm{s}$, respectively. The strong influence of temperature on the water diffusion coefficient was adequately described by an Arrhenius-type equation with activation energy values for Asontem, Hewale and Asomdwee as $7.27 \mathrm{~kJ} / \mathrm{mol}, 7.26 \mathrm{~kJ} / \mathrm{mol}$ and $6.26 \mathrm{~kJ} / \mathrm{mol}$, respectively.
\end{abstract}

\section{Keywords}

Cowpea, Water Absorption, Diffusion Coefficient, Arrhenius-Type Equation, Modelling

\section{Introduction}

Cowpea (Vigna unguiculata) is an essential member of the legume family Fabaceae. It is widely consumed in many parts of the world including Ghana. It is considered one of the crops which have been in existence for many years. On 
average it contains $23.4 \%, 11 \%, 3.6 \%, 1.3 \%$ and $56.8 \%$ of protein, water, ash, fat, carbohydrate, respectively [1]. Generally, processing of cowpea seeds requires initial soaking of seeds in water to allow water absorption by seeds for a period of time before additional processing of the seeds takes place [2]. The rate of water absorption by the seeds largely depends on soaking temperature and soaking time [3]. An increase in soaking temperature results in an increase in the rate of water absorption [4]. The rate of water absorption also depends on the initial moisture content of seeds, variety of seeds, soaking duration, acidity level of soaking water and seed physical characteristics [5] [6]. From process optimization and engineering perspective, it is important to know the rate of water absorption by seeds and the effect of processing variables on the seeds with time during the soaking period [7]. Consequently, for industrial purposes, whether in designing food processing equipment or determining favorable conditions under which soaking can be carried out and how these conditions change with time and temperature, it is necessary to have measurable data which describe the effect of the processing variables on agricultural materials [8] [9] [10]. Several hydration models such as the exponential model, the Peleg's model, first-order kinetics, Becker's model among others have been developed by various researchers to predict rehydration of several legume seeds [11] [12] [13]. The Peleg model and the phenomenological models derived from Fick's diffusion are mostly used in the rehydration of legumes seeds [14] [15]. However, the rehydration model for effects of processing variables on the rate of water uptake and moisture diffusivity in some existing legumes grown in Ghana, such as Asontem, Hewale and Asomdwee cowpea varieties have not been established. Thus, this research was undertaken to study the influence of temperature on the water absorption characteristics of three newly-developed cowpea varieties grown in Ghana.

\section{Materials and Methods}

\subsection{Preparation of Cowpea Seeds}

Samples of three cowpea varieties (Asontem, Hewale and Asomdwee) were obtained from the Council for Scientific and Industrial Research-Crops Research Institute (CSIR-CRI) at Fumesua, Kumasi, Ghana. The seeds were cleaned manually to remove all foreign matter viz. dirt, stones fragments, weevil contaminated seeds and broken seeds. The cleaned seeds were sealed in labelled transparent low density polyethylene bags and stored at $4^{\circ} \mathrm{C}$ to prevent moisture loss and recontamination.

\subsection{Determination of Seed Moisture Content}

The initial moisture contents of the samples of three cowpea varieties were determined in triplicate by oven drying method. $15 \mathrm{~g}$ of each sample was heated in an oven at $103^{\circ} \mathrm{C}$ for $72 \mathrm{~h}$ according to [16] and expressed as $\mathrm{kg} / \mathrm{kg}$ (dry basis). The following equation was used in determining the initial moisture content:

$$
M_{d}=\frac{100-M_{w}}{100 \times M_{w}}
$$


$M_{d}=$ moisture content (dry basis).

$M_{w}=$ moisture content (wet basis).

\subsection{Determination of Seed Dimensions}

The basic dimensions (length (L), breadth (B) and thickness (T) all in millimeters) of sample seeds from each cowpea variety were determined in triplicate using a digital Vernier caliper with a least count of $0.02 \mathrm{~mm}$ for each single seed of 10 seeds sampling before soaking and average value was determined for each sample. A seed each was placed within the Vernier caliper measuring unit and the nob adjusted until the seed was just closely held before taking its reading [17].

\subsection{Determination of Equivalent Radius}

The equivalent radius (R) was determined for 50 seeds from each cowpea variety. The assumption was that the volume of the cowpea seed can be approximated by calculating the volume of a sphere with radius equal to half diameter of the seed. To determine the volume of the seed, $50 \mathrm{ml}$ of distilled water was transferred into a measuring cylinder of $100 \mathrm{ml}$ capacity. Afterward, 50 seeds of each cowpea variety were separately immersed in the water one variety at a time. The amount of water displaced was read on the measuring cylinder and recorded accordingly. The procedure was replicated five times and the true volume $(V)$ was calculated in $\mathrm{mm}^{3}$ and equivalent radius $(R)$ is given by Equation (2):

$$
R=\sqrt[3]{\frac{3 V}{4 \pi}}
$$

$V=$ volume of seed $\left(\mathrm{mm}^{3}\right)$.

\subsection{Soaking Experiment}

The water absorption characteristics of the three cowpea varieties were determined by soaking them at four different water temperatures $\left(30^{\circ} \mathrm{C} \pm 2^{\circ} \mathrm{C}\right.$, $40 \pm 2^{\circ} \mathrm{C}, 50^{\circ} \mathrm{C} \pm 2^{\circ} \mathrm{C}$, and $60^{\circ} \mathrm{C} \pm 2^{\circ} \mathrm{C}$ in a thermostatic water bath for $10 \mathrm{~h}$. Three replicates of sample size of $10 \mathrm{~g} \pm 0.02 \mathrm{~g}$ were separately placed in a mesh, tied and labelled before they were placed into the portable water bath. The samples were removed at predetermined time interval of 30 minutes. The samples were placed on soft moisture absorbing tissues after untying the nets. The seeds were blotted with tissue paper to absorb remaining water on the surface of the seeds before the seed samples were reweighed [18], as cited by [17].

\subsection{Soaking Experiment}

The water absorption capacity of seeds of each cowpea hybrid was determined using Equation (3) by [19]:

$$
W_{a c}=\frac{W_{f}-W_{i}}{W_{i}}
$$


$W_{a c}=$ water absorption capacity (d.b. \%) of seeds.

$W_{f}=$ weight of seeds (g) after immersion into water.

$W_{i}=$ weight of seeds $(\mathrm{g})$ before immersion into water.

\subsection{Modelling of Rehydration Kinetics}

Many studies on water absorption and drying use the moisture ratio (MR) as the basis for achieving water absorption and drying models as a result of few data dispersion and optimize data [20]. Normally, when a diffusion process takes place at a temperature, which is constant, that process is believed to exhibit Fick's second law of diffusion. As stated by Fick, a diffusion process which is axisymmetric in nature can be expressed using an equation that is three-dimensional given by:

$$
\frac{\partial M}{\partial t}=D\left(\frac{\partial^{2} M}{\partial x^{2}}+\frac{\partial^{2} M}{\partial y^{2}}+\frac{\partial^{2} M}{\partial z^{2}}\right)
$$

$$
\begin{aligned}
& M=\text { instantaneous moisture at specified time }(\mathrm{kg} / \mathrm{kg}) \\
& D=\text { diffusion coefficient }\left(\mathrm{m}^{2} / \mathrm{s}\right) \\
& t=\text { time }(\mathrm{s})
\end{aligned}
$$

[21], proposed a model to determine the diffusion coefficient, $D$. The model is an equation which shows the relationship between moisture concentration and time for particles of random shape as well as relative short immersion times. The equation is given as:

$$
\begin{gathered}
1-\left(\frac{U-U_{s}}{U_{o}-U_{s}}\right)=\frac{2}{\pi^{1 / 2}} F_{o}^{1 / 2} \\
F_{o}=\frac{D \theta}{R^{2}}
\end{gathered}
$$

$U=$ mean moisture concentration in dry weight $(\mathrm{g} / \mathrm{g})$.

$U_{s}=$ saturation moisture concentration in dry weight $(\mathrm{g} / \mathrm{g})$.

$U_{o}=$ initial moisture concentration in dry weight $(\mathrm{g} / \mathrm{g})$.

$D=$ diffusion coefficient $\left(\mathrm{m}^{2} / \mathrm{s}\right)$.

$R=$ equivalent radius of the sphere with the same volume as that of particle under consideration.

$\theta=$ soaking or immersion time (s).

Temperature dependency of diffusion coefficient was described by Arrhenius Equation (7):

$$
D=D_{0} \mathrm{e}^{-E / R T}
$$

$D_{0}=$ diffusion constant $\left(\mathrm{m}^{2} / \mathrm{s}\right)$.

$E=$ activation energy $(\mathrm{kJ} / \mathrm{mol})$.

$R=$ gas constant $(8.314 \mathrm{~kJ} / \mathrm{molK})$.

$T=$ absolute temperature $(\mathrm{K})$.

Linear regression analysis of ( $\mathrm{D}$ vs. $1 / \mathrm{T}$ ) was used to determine activation energy values for the different cowpea varieties under consideration. The linear re- 
gression analysis gave slope value indicating (E/R). A product of the slope (E/R) value and gas constant $(\mathrm{R})$ produced the activation energy values for Asontem, Hewale and Asomdwee cowpea seeds.

\subsection{Experimental Design}

The soaking experiment was performed in a factorial form in a completely randomized design with three replications to study the influence soaking temperature on water absorption capacity of samples of three cowpea varieties.

\section{Results}

\subsection{Initial Physical Properties of Cowpea Varieties}

The initial physical properties of the three cowpea varieties (Asontem, Hewale and Asomdwee) determined before soaking at different temperatures are given in Table 1.

\subsection{Water Absorption Characteristics of Asontem, Hewale and Asomdwee}

The water absorption characteristics of Asontem, Hewale and Asomdwee cowpea varieties are shown in Figures 1-3.

\subsection{Saturation Moisture Content $\left(\mathrm{U}_{s}\right)$ and Diffusion Coefficient (D) of Asontem, Hewale and Asomdwee Cowpea Varieties}

The saturation moisture contents and diffusion coefficients of Asontem, Hewale and Asomdwee cowpea varieties are shown in Tables 2-4.

\subsection{Water Absorption Rate of Asontem, Hewale and Asomdwee cowpea}

The water absorption rate of Asontem, Hewale and Asomdwee cowpea varieties during soaking at temperatures of $30^{\circ} \mathrm{C}, 40^{\circ} \mathrm{C}, 50^{\circ} \mathrm{C}$ and $60^{\circ} \mathrm{C}$ are given in Figures 4-6.

Table 1. Physical properties of Asontem, Hewale and Asomdwee cowpea varieties.

\begin{tabular}{cccc}
\hline & \multicolumn{3}{c}{ Cowpea Variety } \\
\hline Physical Property & Asontem & Hewale & Asomdwee \\
\hline Moisture content (\%d.b.) & $16.53 \pm 0.00$ & $12.40 \pm 0.01$ & $13.63 \pm 0.00$ \\
Length (mm) & $7.19 \pm 0.75$ & $6.88 \pm 0.72$ & $7.20 \pm 0.46$ \\
Breadth (mm) & $6.01 \pm 0.42$ & $5.54 \pm 0.43$ & $5.44 \pm 0.32$ \\
Thickness (mm) & $4.78 \pm 0.28$ & $4.45 \pm 0.34$ & $4.63 \pm 0.24$ \\
Radius (mm) & $3.46 \pm 0.38$ & $3.26 \pm 0.37$ & $3.08 \pm 0.64$ \\
Surface area (mm $\left.{ }^{2}\right)$ & $111.00 \pm 18.30$ & $96.44 \pm 13.34$ & $100.81 \pm 9.32$ \\
\hline
\end{tabular}




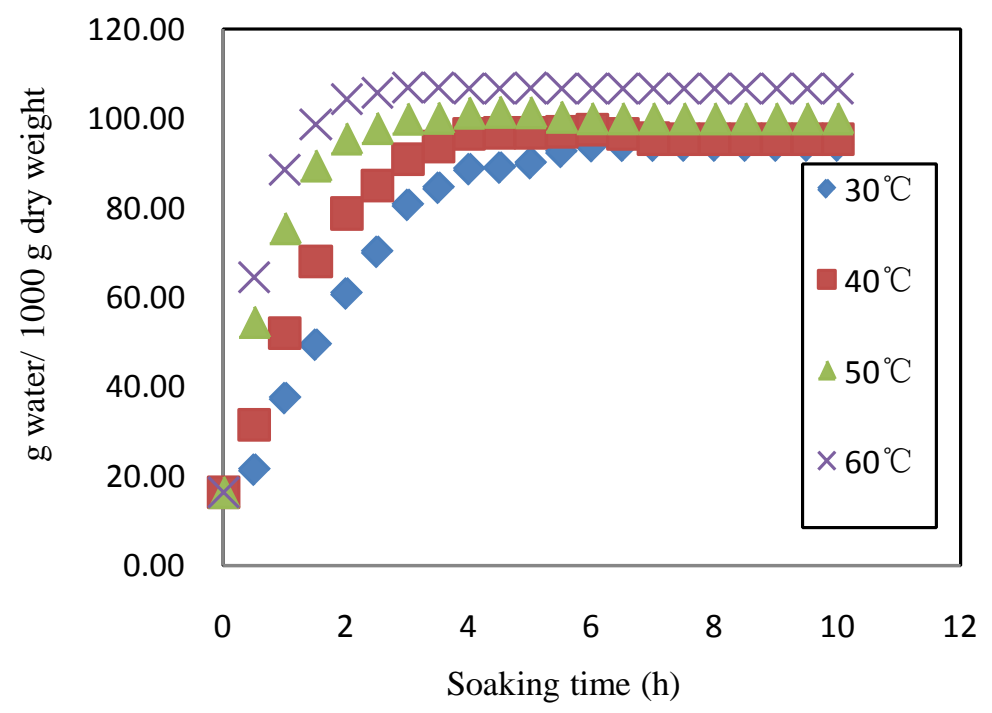

Figure 1. Water absorption characteristics of Asontem.

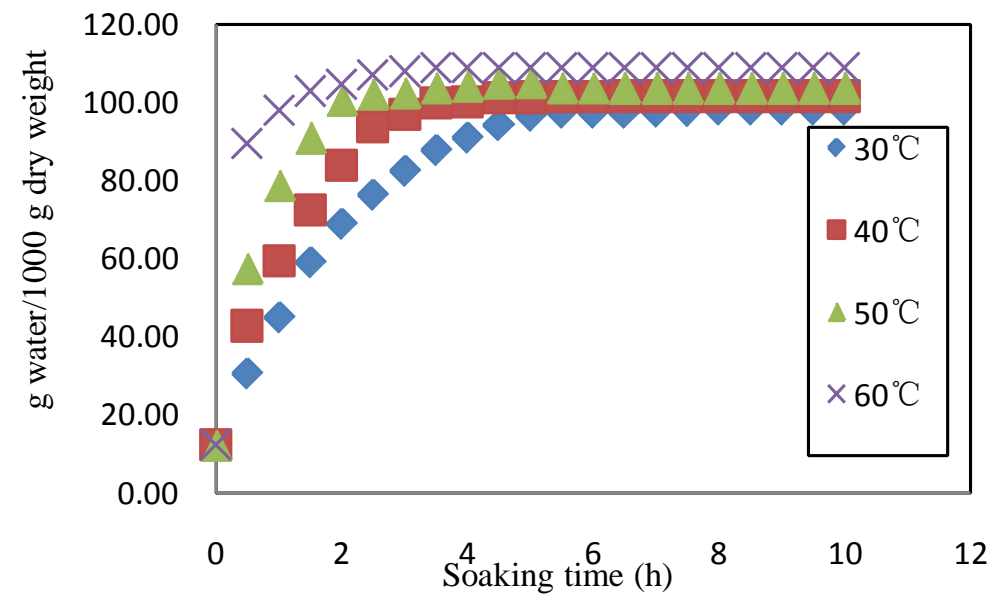

Figure 2. Water absorption characteristics of Hewale.

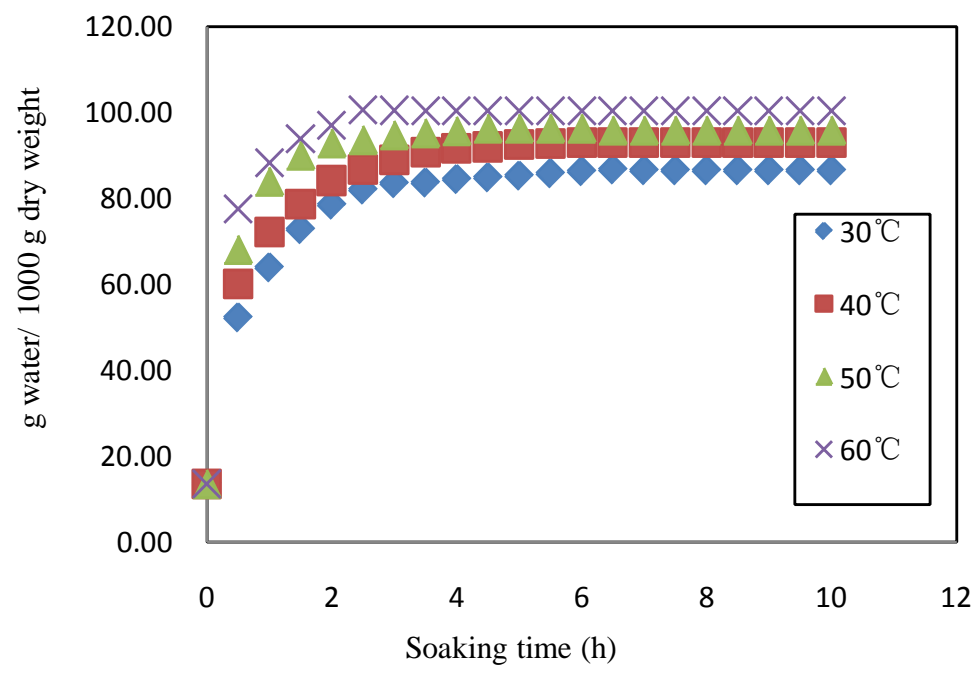

Figure 3. Water absorption characteristics of Asomdwe. 


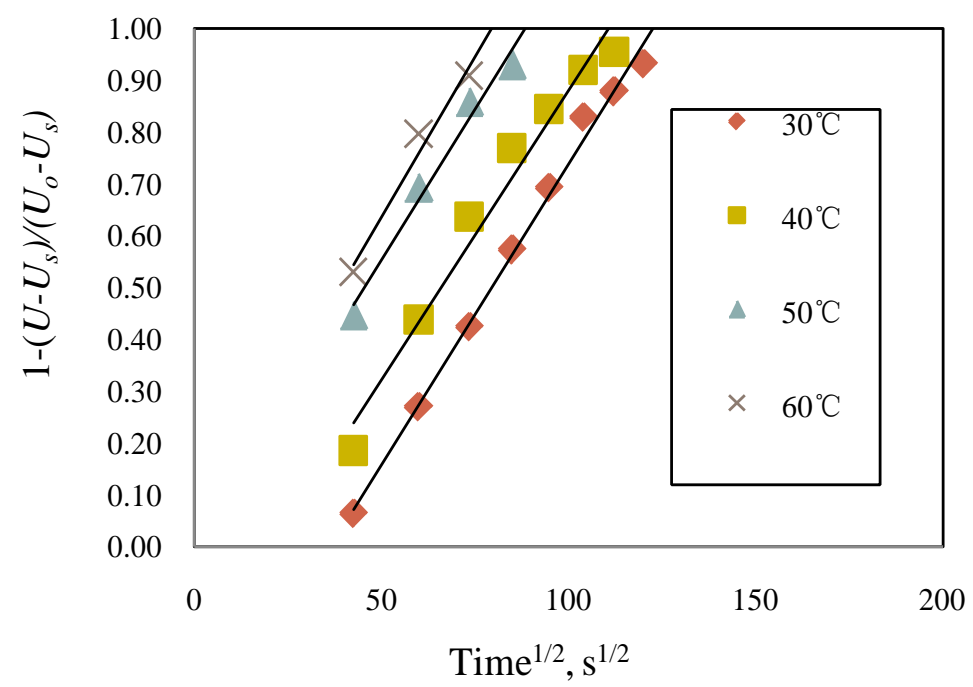

Figure 4. Water absorption rate for Asontem.

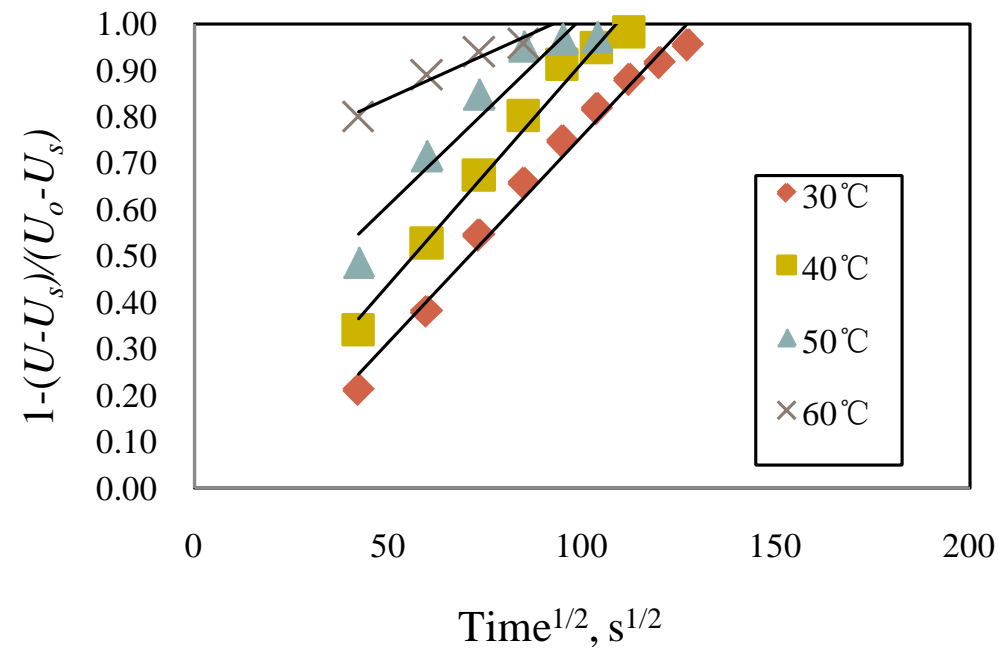

Figure 5. Water absorption rate for Hewale.

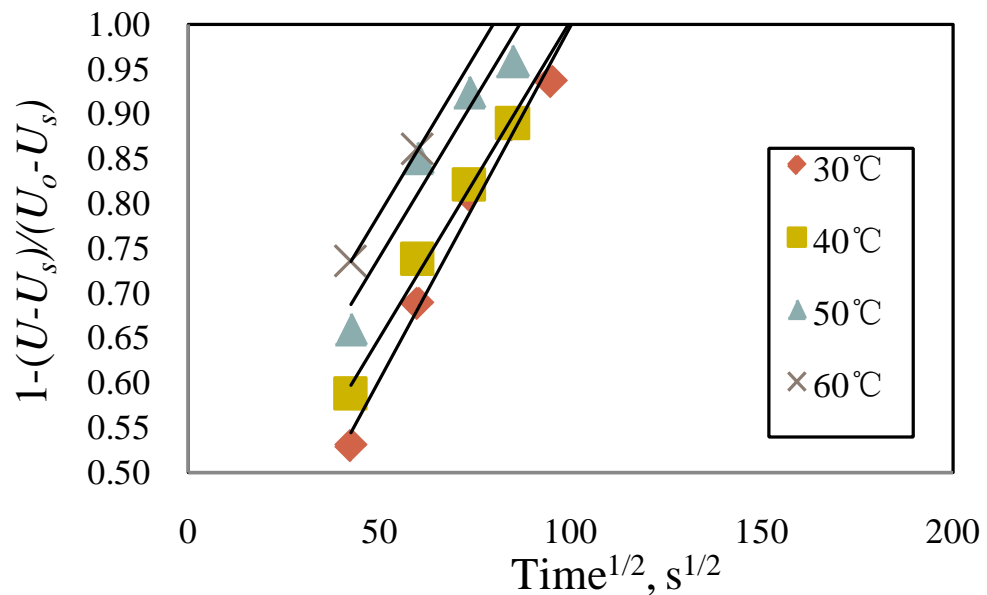

Figure 6. Water absorption rate for Asomdwee. 
Table 2. Saturation moisture content $\left(\mathrm{U}_{\mathrm{s}}\right)$ and diffusion coefficient $(\mathrm{D})$ of Asontem cowpea variety at different soaking temperatures.

\begin{tabular}{ccccc}
\hline & \multicolumn{5}{c}{ Temperature $\left({ }^{\circ} \mathrm{C}\right)$} \\
\hline Parameter & 30 & 40 & 50 & 60 \\
\hline $\mathrm{U}_{\mathrm{s}}$ & 93.9 & 97.6 & 101.5 & 106.9 \\
$\mathrm{D} \times\left(10^{-10} \mathrm{~m}^{2} / \mathrm{s}\right)$ & 5.12 & 5.69 & 6.19 & 6.64 \\
$\mathrm{R}^{2}$ & 0.93 & 0.89 & 0.88 & 0.87 \\
\hline
\end{tabular}

Table 3. Saturation moisture content (Us) and diffusion coefficient (D) of Hewale cowpea variety at different soaking temperatures.

\begin{tabular}{ccccc}
\hline & \multicolumn{5}{c}{ Temperature $\left({ }^{\circ} \mathrm{C}\right)$} \\
\hline Parameter & 30 & 40 & 50 & 60 \\
\hline $\mathrm{U}_{\mathrm{s}}$ & 98.3 & 101.5 & 104.9 & 108.7 \\
$\mathrm{D} \times\left(10^{-10} \mathrm{~m}^{2} / \mathrm{s}\right)$ & 3.96 & 4.38 & 4.85 & 5.12 \\
$\mathrm{R}^{2}$ & 0.95 & 0.91 & 0.84 & 0.96 \\
\hline
\end{tabular}

Table 4. Saturation moisture content $\left(U_{s}\right)$ and diffusion coefficient (D) of Asomdwee cowpea variety at different soaking temperatures.

\begin{tabular}{ccccc}
\hline & \multicolumn{5}{c}{ Temperature $\left({ }^{\circ} \mathrm{C}\right)$} \\
\hline Parameter & 30 & 40 & 50 & 60 \\
\hline $\mathrm{U}_{\mathrm{s}}$ & 86.8 & 92.9 & 96.4 & 100.7 \\
$\mathrm{D} \times\left(10^{-10} \mathrm{~m}^{2} / \mathrm{s}\right)$ & 4.93 & 5.16 & 5.80 & 6.08 \\
$\mathrm{R}^{2}$ & 0.80 & 0.87 & 0.82 & 0.97 \\
\hline
\end{tabular}

\section{Discussions}

\subsection{Initial Physical Properties of Cowpea Varieties}

The initial moisture content for Asontem cowpea was higher than that ofAsomdwee and Hewale cowpea varieties. The data presented in Table 1 generally agree with those reported by [22], who reported values ranging from 0.73 $\mathrm{cm}-0.92 \mathrm{~cm}$ for length, $0.55 \mathrm{~cm}-0.73 \mathrm{~cm}$ for breadth and $0.38 \mathrm{~cm}-0.58 \mathrm{~cm}$ for thickness of cowpea seeds. Furthermore, [23] reported similar range of values for length, breadth and thickness of cowpea seeds. Asontem also exhibited generally higher values for its principal dimensions with the exception of its average length which was slightly lower than that of Asomdwee. However, the values for equivalent radius and the surface area of Asontem were highest in comparison to Asomdwee and Hewale.

\subsection{Water Absorption Characteristics of Asontem, Hewale and Asomdwee}

It is seen from Figures 1-3 that the rate of water absorption by cowpea seeds increased as the soaking temperatures increased. [11] [24] and [25] reported simi- 
lar results from their studies on the water absorption characteristics of Soybean and chickpea. [26] Also made comparable observation when they studied on the water absorption characteristics of soybean seeds. During the soaking process, an initial instant rate of water absorption was observed after which the rate of water absorption gradually slowed down as the saturation moisture content was approached at all four temperatures. This was because the force driving the water absorption into the seeds decreased as the rate of water absorption neared saturation moisture content [27]. The time taken for saturation moisture content for all the cowpea varieties to be reached was longer during soaking at $30^{\circ} \mathrm{C}$ but decreased with increasing temperatures. This is because the higher the temperature, the higher the rate of water diffusion into the seeds. Again higher temperatures mean faster gelatinization of starch content of seeds and faster denatured protein resulting in faster rate of water absorption. The time taken for saturation moisture content for Asontem cowpea to be reached was at $8 \mathrm{~h}$ during soaking at $30^{\circ} \mathrm{C}$, but it reduced to $6 \mathrm{~h}, 4.5 \mathrm{~h}$ and $3 \mathrm{~h}$ when soaking was carried out at $40^{\circ} \mathrm{C}$, $50^{\circ} \mathrm{C}$ and $60^{\circ} \mathrm{C}$, respectively. The time taken for saturation moisture content to be achieved for Hewale cowpea during soaking at $30^{\circ} \mathrm{C}$ was also $8 \mathrm{~h}$ but it also reduced to $6.5 \mathrm{~h}, 5 \mathrm{~h}$ and $3.5 \mathrm{~h}$ as the soaking temperature of the water was increased to $40^{\circ} \mathrm{C} 50^{\circ} \mathrm{C}$ and $60^{\circ} \mathrm{C}$, respectively. Similar results were obtained for Asomdwee cowpea variety whose saturation moisture content was reached at 6.5 $\mathrm{h}, 6 \mathrm{~h}, 4.5 \mathrm{~h}$ and $2.5 \mathrm{~h}$ during soaking at $30^{\circ} \mathrm{C}, 40^{\circ} \mathrm{C} 50^{\circ} \mathrm{C}$ and $60^{\circ} \mathrm{C}$, respectively. Similar results were reported by [17] when they studied the water absorption characteristics of two maize varieties: Obatanpa and Mamaba.

\subsection{Saturation Moisture Content $\left(U_{s}\right)$ and Diffusion Coefficient (D) of Asontem, Hewale and Asomdwee Cowpea Varieties}

The diffusion coefficients of the three cowpea varieties (Asontem, Hewale and Asomdwee) during water absorption were determined using Equation (5) and Equation (6). The factors from the linear regression analyses: the diffusion coefficient, saturation moisture content and the coefficient of determination are shown in Tables 2-4. The saturation moisture content for all the three cowpea varieties increased as the soaking temperatures increased, although the rates at which increment in saturation moisture contents occurred between the initial and final soaking temperatures were not the same for the three different cowpea varieties. The values obtained for the coefficient of determination ranged from 0.80 to 0.97 indicating an extremely good fit to the data obtained from the experiment. The water absorption rates for Asontem, Hewale and Asomdwee cowpea varieties are shown in Figures 4-6. From Table 2, the diffusion coefficient values of Asontem cowpea seeds ranged from $5.12 \times 10^{-10} \mathrm{~m}^{2} / \mathrm{s}$ to $6.64 \times$ $10^{-10} \mathrm{~m}^{2} / \mathrm{s}$ which were higher than those of Asomdwee cowpea seeds in Table 4 ranging from $4.93 \times 10^{-10} \mathrm{~m}^{2} / \mathrm{s}$ to $6.08 \times 10^{-10} \mathrm{~m}^{2} / \mathrm{s}$ and Hewale cowpea in Table 3 ranging from $3.96 \times 10^{-10} \mathrm{~m}^{2} / \mathrm{s}$ to $5.12 \times 10^{-10} \mathrm{~m}^{2} / \mathrm{s}$, respectively. This outcome could be as a result of the variations in their seed characteristics since they are different varieties of cowpea [28]. According to [29], proteins and carbohydrates 
are the main constituents of seeds, which have the ability to absorb so much water, with proteins having a higher water absorption power than carbohydrates. Thus, the differences in the nutritional compositions of Asontem, Hewale and Asomdwee cowpea seeds could also be another reason for the diffusion coefficient values of Asontem cowpea seeds being higher than that of the other two cowpea varieties. It is therefore possible that Asontem cowpea seeds have higher protein content than that of Hewale and Asomdwee, making Asontem cowpea seeds absorb more water than the other two cowpea varieties under the same temperature treatments and the same soaking time. In contrast to the diffusion coefficient values (common treatment: $7.75 \times 10^{-11} \mathrm{~m}^{2} / \mathrm{s}$ to $1.99 \times 10^{-10} \mathrm{~m}^{2} / \mathrm{s}$ and microwave treatment: $2.23 \times 10^{-9} \mathrm{~m}^{2} / \mathrm{s}$ to $9.78 \times 10^{-9} \mathrm{~m}^{2} / \mathrm{s}$ ) reported by [5], the diffusion values reported in this study were lower but similar to the values of $4.35 \times 10^{-11} \mathrm{~m}^{2} / \mathrm{s}$ to $3.79 \times 10^{-9} \mathrm{~m}^{2} / \mathrm{s}$ and $1.99 \times 10^{-10} \mathrm{~m}^{2} / \mathrm{s}$ to $39.16 \times 10^{-10} \mathrm{~m}^{2} / \mathrm{s}$ reported by [18] and [30].

\subsection{Water Absorption Rate of Asontem, Hewale and Asomdwee Cowpea Varieties}

The values of the diffusion coefficients of Asontem, Asomdwee and Hewale cowpea varieties were fitted to Arrhenius equation in order to describe the temperature effect on the moisture diffusivity of the three cowpea varieties, with the coefficient of determination, $\mathrm{R}^{2}$, which ranged from 0.96 to 0.99 . Figure 7 shows the Arrhenius relation for the diffusion coefficients and temperature of Asontem, Hewale and Asomdweecowpea varieties. It shows the existence of a linear relationship between the diffusion coefficients and the reciprocal absolute temperatures used in the soaking experiment. In addition, the Arrhenius equation was extremely adequate in describing the effect or influence of temperature on the absorption of moisture by the seeds of all the three cowpea varieties. From Table 5, the temperature sensitivity of the diffusion coefficient, D, was highest for Asontem cowpea variety with activation energy of $7.27 \mathrm{~kJ} / \mathrm{mol}$, the second highest being Hewale cowpea variety with activation energy of $7.26 \mathrm{~kJ} / \mathrm{mol}$ and lowest for Asomdwee cowpea variety with activation energy of $6.26 \mathrm{~kJ} / \mathrm{mol}$. The values of activation energy obtained for the three cowpea varieties were similar to those reported by [17] for two maize varieties: Obatanpa and Mamaba. Obatanpa maize variety had activation energy value of $6.54 \mathrm{~kJ} / \mathrm{mol}$ while Mamaba maize variety had activation energy of $6.82 \mathrm{~kJ} / \mathrm{mol}$. However, in comparison to other studies, the activation energy values obtained for the three cowpea varieties were significantly smaller. [22], reported activation energy value of $11.20 \mathrm{~kJ} / \mathrm{mol}$ for white bambara groundnut [7], also reported an activation energy value of $28.38 \mathrm{~kJ} / \mathrm{mol}$ for Egusi melon seeds, whereas [18] reported higher activation energy values for soybean.

\section{Conclusion}

The water absorption kinetics of three cowpea varieties (Asontem, Hewale and Asomdwee) was studied following the phenomenological models derived from 


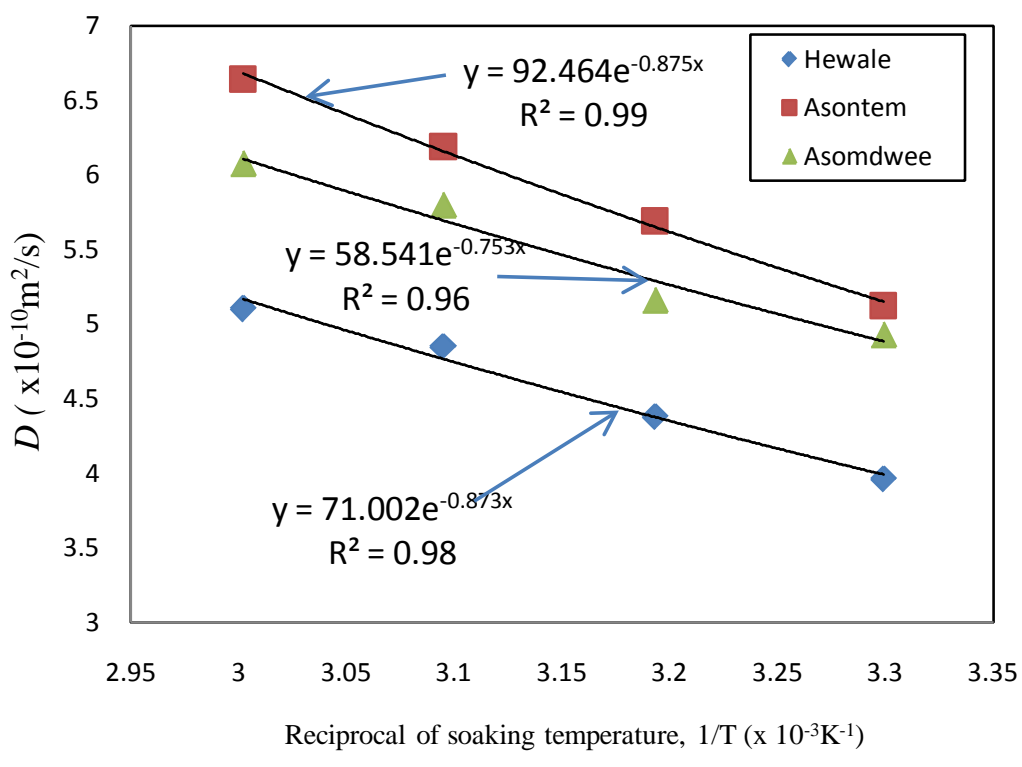

Figure 7. Relationship between Diffusion Coefficients And Temperature for Asontem, Hewale and Asomdwee.

Table 5. Activation energy values during soaking of Asontem, Hewale and Asomdwee cowpea varieties.

\begin{tabular}{ccc}
\hline Cowpea variety & Activation energy $(E)$ & $\mathrm{R}^{2}$ \\
\hline Asontem & 7.27 & 0.99 \\
Hewale & 7.26 & 0.98 \\
Asomdwee & 6.26 & 0.96 \\
\hline
\end{tabular}

Fick's law of diffusion. The time taken for Asontem, Hewale and Asomdwee cowpea varieties to reach saturation moisture content during soaking decreased from $8 \mathrm{~h}$ to $3 \mathrm{~h}, 8 \mathrm{~h}$ to $3.5 \mathrm{~h}$ and $6 \mathrm{~h}$ to $5 \mathrm{~h}$, respectively, by the increase in soaking temperature from $30^{\circ} \mathrm{C}$ through to $60^{\circ} \mathrm{C}$. A reasonable forecast of water absorption by Asontem, Hewale and Asomdwee cowpea varieties during soaking was achieved by fitting of the experimental data to Fick's diffusion law. The water diffusion coefficients for Asontem, Hewale and Asomdwee cowpea varieties, within temperature variation from $30^{\circ} \mathrm{C}$ to $60^{\circ} \mathrm{C}$, ranged from $5.12 \times 10^{-10} \mathrm{~m}^{2} / \mathrm{s}$ to $6.64 \times 10^{-10} \mathrm{~m}^{2} / \mathrm{s}, 3.96 \times 10^{-10} \mathrm{~m}^{2} / \mathrm{s}$ to $5.12 \times 10^{-10} \mathrm{~m}^{2} / \mathrm{s}$ and $4.93 \times 10^{-10} \mathrm{~m}^{2} / \mathrm{s}$ to $6.08 \times 10^{-10} \mathrm{~m}^{2} / \mathrm{s}$, respectively. The intense influence of temperature on the water diffusion coefficient was adequately described by an Arrhenius-type equation giving activation energy values of Asontem, Hewale and Asomdwee cowpea varieties as $7.27 \mathrm{~kJ} / \mathrm{mol}, 7.26 \mathrm{~kJ} / \mathrm{mol}$ and $6.26 \mathrm{~kJ} / \mathrm{mol}$, respectively.

\section{Acknowledgements}

The authors express their appreciation to the CSIR-Food Research Institute, Accra, and the Agricultural and Biosytems Engineering Department of KNUST, Kumasi. 


\section{Conflicts of Interest}

The authors declare that there is no conflict of interest regarding the publication of this paper.

\section{References}

[1] Davies R.M. and Zibokere, D.S. (2011) Effect of Moisture Content on Some Physical and Mechanical Properties of Three Varieties of Cowpea (Vigna unguiculata (L) Walp). Agricultural Engineering International: CIGR Journal, 13, 1-16. http://www.cigrjournal.org/index.php/Ejounral/article/viewFile/1700/1397

[2] El-Syiad, S.I. and Hassan, M.A.M. (2014) Quality of White Bean Seeds (Phaseolus vulgaris L.) as Affected by Different Treatments. World Journal of Dairy and Food Sciences, 9, 20-28.

[3] Shafaei, S.M. and Masoumi, A.A. (2014) Estimating Moisture Absorption Kinetics of Beans during Soaking Using Mathematical Models. CIGR Journal, 16, 231-237.

[4] Kashaninejadl, M. and Kashiri, M. (2007) Hydration Kinetics and Changes in Some Physical Properties of Wheat Kernels. Journal of Iranian Food Science and Tech. Research, 45, 58-59.

[5] Demirhan, E. and Özbek, B. (2015) Modeling of the Water Uptake Process for Cowpea Seeds (Vigna unguiculata L.) under Common Treatment and Microwave Treatment. Journal of Chemical Society of Pakistan, 37, 1-10.

[6] Baryeh, E.A. (2001) Physical Properties of Bambara Groundnuts. Journal of Food Engineering, 47, 321-326. https://doi.org/10.1016/S0260-8774(00)00136-9

[7] Addo, A. and Bart-Plange, A. (2009) Kinetics of Water Sorption by Egusi Melon (Cucumeropsis edulis) Seeds. ARPN Journal of Agricultural and Biological Science, 4, 14-17.

[8] Bhattacharya, S. (1995) Kinetics of Hydration of Raw and Roasted Corn Semolina. Journal of Food Engineering, 25, 21-30. https://doi.org/10.1016/0260-8774(95)93013-L

[9] Abu-Ghannam, N. and McKenna, B. (1997) Hydration Kinetics of Red Kidney Beans (Phaseolus vulgaris L.). Journal of Food Science, 62, 520-523. https://doi.org/10.1111/j.1365-2621.1997.tb04420.x

[10] Taiwo, K.A., Akanbi, C.T. and Ajibola, O.O. (1994) Effect of Soaking Conditions on Water Absorption and Texture of Two Cowpea Varieties (Vigna ungunculata). Nigerian Food Journal, 12, 11-18.

[11] Turhan, M., Sayar, S. and Gunasekaran, S. (2001) Application of Peleg Model to Study Water Absorption in Chickpea during Soaking. Journal of Food Engineering, 53, 153-159. https://doi.org/10.1016/S0260-8774(01)00152-2

[12] Vengaiah, P.C., Raigar, R.K., Srivastav, P.P. and Majumdar, G.C. (2012) Hydration Characteristics of Wheat Grain. Agricultural Engineering International: CIGR Journal, 14, 116-119.

[13] Lu, R., Siebenmorgen, T.J. and Archer, T.R. (1994) Absorption of Water in Long-Grain Rough Rice during Soaking. Journal of Food Process Engineering, 17, 141-154. https://doi.org/10.1111/j.1745-4530.1994.tb00332.x

[14] Hsu, K.H. (1983) A Diffusion Model with a Concentration-Dependent Diffusion Coefficient for Describing Water Movement in Legumes during Soaking. Journal of Food Science, 48, 618-622. https://doi.org/10.1111/j.1365-2621.1983.tb10803.x

[15] Tang, J., Sokhansanj, S. and Sosulski, F.W. (1994) Moisture-Absorption Character- 
istics of Laird Lentils and Hard Shell Seeds. Cereal Chemistry, 71, 423-428.

[16] ASAES352.2 APR1988 (2012) Moisture Measurement-Unground Grain and Seeds.

[17] Addo, A., Bart-Plange, A. and Dzisi, K. (2006) Water Absorption Characteristics of Obatanpa and Mamaba Maize Hybrids (Zea mays). International Journal of Food Engineering, 2, 1556-3758. https://doi.org/10.2202/1556-3758.1067

[18] Seyhan-Gurtas, F., Ak, M.M. and Evranuz, E.O. (2001) Water Diffusion Coefficients of Selected Legumes Grown in Turkey as Affected by Temperature and Variety. Turkish Journal of Agriculture, 25, 297-304.

[19] McWatters, K.H., Chinnan, M.S., Phillips, R.D., Beuchat, L.R., Reid, L.B. and Mensa-Wilmot, R.M. (2002) Functional, Nutritional, Myco-Logical and Akara-Making Properties of Stored Cowpea Meal. Journal of Food Science, 67, 2229-2234. https://doi.org/10.1111/j.1365-2621.2002.tb09532.x

[20] Akpinar, E.K., Bicer, Y. and Yildiz, C. (2003) Thin Layer Drying of Red Pepper. Journal of Food Engineering, 59, 99-104. https://doi.org/10.1016/S0260-8774(02)00425-9

[21] Becker, H.A. (1960) On the Absorption of Liquid Water by the Wheat Kernel. Cereal Chemistry, 37, 309-323.

[22] Kaptso, K.G., Njintang, Y.N., Komnek, A.E., Hounhouigan, J., Scher, J. and Mbofung, C.M.F. (2008) Physical Properties and Rehydration Kinetics of Two Varieties of Cowpea (Vigna unguiculata) and Bambara Groundnuts (Voandzeia subterranea) Seeds. Journal of Food Engineering, 86, 91-99. https://doi.org/10.1016/j.jfoodeng.2007.09.014

[23] Olapade, A.A., Okafor, G.I., Ozumba, A.U. and Olatunji, O. (2002) Characterization of Common Nigerian Cowpea (Vigna unguiculata L. Walp) Varieties. Journal of Food Engineering, 55, 101-105. https://doi.org/10.1016/S0260-8774(02)00022-5

[24] Sopade, P.A. and Obekpa, J.A. (1990) Modelling Water Absorption in Soybean, Cowpea and Peanuts at Three Temperatures Using Peleg's Equation. Journal of Food Science, 55, 1084-1087. https://doi.org/10.1111/j.1365-2621.1990.tb01604.x

[25] Shafaei, S.M., Masoumi, A.A. and Roshan, H. (2014) Analysis of Water Absorption of Bean and Chickpea during Soaking Using Peleg Model. Journal of the Saudi Society of Agricultural Sciences, 15, 135-144.

[26] Pan, Z. and Tangratanavalee, W. (2003) Characteristics of Soybeans as Affected by Soaking Conditions. LWT-Food Science and Technology, 36, 143-151. https://doi.org/10.1016/S0023-6438(02)00202-5

[27] Kashiri, M., Kashaninejad, M. and Aghajani, N. (2010) Modelling Water Absorption of Sorghum during Soaking. Latin American Applied Research, 40, 383-388.

[28] Haros, M., Viollaz, P.E. and Suarez, C. (1995) Effect of Temperature and $\mathrm{SO}_{2}$ on the Rates of Water Absorption of Three Maize Hybrids. Journal of Food Engineering, 25, 473-482. https://doi.org/10.1016/0260-8774(94)00022-2

[29] Agarry, S.E., Afolabi, T.J. and Akintunde, T.T.Y. (2014) Modelling the Water Absorption Characteristics of Different Maize (Zea Mays L.). Types during Soaking. Journal of Food Processing \& Technology, 5, 326. https://doi.org/10.4172/2157-7110.1000326

[30] Thakur Kr., A. and Gupta, A.K. (2006) Water Absorption Characteristics of Paddy, Brown Rice and Husk during Soaking. Journal of Food Engineering, 75, 252-257. https://doi.org/10.1016/j.jfoodeng.2005.04.014 